\title{
SOCIO-ECONOMIC ENVIRONMENT OF THE COMPANY AND THE NEED FOR COUNTABLE FINANCIAL INFORMATION
}

Prep. drd. Loredana Tănase - Universitatea Valahia din Târgoviște, e-mail: loredanatanase@valahia.ro

Rezumat:

Within the framework of the European single market and its regulations, there is not any more a doubt that only the companies which will be able to thrive are those which, not only are in measurement, because they there are prepared, to make economic and financial decisions dynamic, but which, moreover, use all the tools placed at their disposal to detect in a precise way the points strong and weak their competitors in order to take an action aiming at a share of increasingly broad market. Countable the European harmonization of laws and the obligation to publish the annual statements (assessment, income statement, appendices) are two elements which facilitate the comparative analysis of the financial statements, mainly on the level of balance (or imbalance) financial, and of the performances carried out.

Since many years already, each one agrees to qualify our economic situation of alarming. If we hold to detect principal the two decades changes, we will be able to note that the world rocked of abundance to the shortage, beyond growth with the crisis, inflation and unemployment. More and more, the economic and social actors doubt management, going even until being unaware of certain essential functions of the company. All criticized the systems of analysis without heart, insistent on the damage caused by the interest carried to the files, with the detriment of the individuals.

As very precisely Yves-Aubert Cote in his devoted article underlines it has accountancy and with the control in the mobility of the future: "What changed at our time, it is the rate/rhythm of the interpellations become more frequent, the diversity and the complexity increasing of the raised problems, the extent of the means put in work to answer waiting more quickly than before, the strength of the countable institutions which is resulted from it with growing and increasingly influential external forces. Nothing lets predict the weakening of these tendencies in the 20 next years".

The principal characteristic of the current management - on which level that it is - it is a permanent need for reliable information, obtained at lower cost.

Is what one era different which is with our doors, made challenges to take up by the companies and their leaders, the professionals of accountancy and the profession itself? Each one is brought to modify at the same time its knowledge, its action and its reflection.

The company of tomorrow and the challenges

To leave the crisis, the company must take a voluntary action, adapting to the market trends. The role of the leader cannot be limited to the survival of the tool of exploitation: the policy to be followed must hold account of the existing data, but also, and especially, be directed towards future prospects.

To establish a dynamic program requires a thorough knowledge of the environment in which the company develops. Indeed, the company is at the same time confronted with external pressures and interns.

The external pressures are, on the one hand, national and international competition, and on the other hand, the intervention of the State which draws the legal framework of the economy while imposing, amongst other things, of the social contributions and tax rigorous, by regulating the capital market, information economic and financial to establish and publish. 
In addition, the internal, inherent pressures in any human organization are also exerted within the company: conflicts of people thirst for the capacity, stops of work.

In this context, the leader has the role of ensuring in the long run:

a) the safety and profitability of capital which is entrusted to him;

b) the safety and the remuneration of the swift services by the men for which it has the responsibility

This double financial and human responsibility, lying within a financial and social scope often restricted, will require of the manager a rigorous and continuous effort, so that the exploitation can survive and progress.

According to A. Vlerick, one never finished undertaking. "All manager of undertaking constantly has the role of adapting to the ceaseless changes of our company. Our time requires of the contractor an adaptation and a permanent renewal. Our time requires of the contractor an adaptation and a permanent renewal. Can our company understand in time that freedom to undertake is the engine of our economy, the source of our employment, and guarantees it of a permanent progress?"

The changes which take shape will oblige any person in charge to answer the five following challenges:

a) the technological challenge

b) the international challenge

c) the social challenge

d) the challenge of the communication

e) the challenge of accountancy and information.

The technological challenge - the importance of technological quality is found at various levels:

- the productivity, allied with the innovation, becomes an inescapable requirement to survive and develop;

- the presence on the domestic markets and external will not be possible that if we are powerful in the manufacture of products of high technology, satisfying unceasingly increasing needs.

In areas where the industrial structure rests on a tool and practices traditional, the technological challenge is difficult to negotiate because it disturbs.

In addition to the modernization of our apparatus of production, the adaptation to the new processes requires a renewal of the state of mind of the leaders and the personnel, as well as behaviors and procedures installation.

The international challenge - during the latter years, the increase in the international exchanges was, for the majority of the country, synonymous with creation of use and but also diversity source of income of the interlocutors, those having their own characteristics and of the distinct potentials of development. To face competition is thing difficult and the return to oneself is not a solution. On the contrary, it is of primary importance that the company faces the competition, by highlighting its strong points, which will enable him to be ready to negotiate and obtain a place of choice in the world trade.

The social challenge - this challenge relates to the social and human evolution. This one sticks, from now on, with values extremely different from those of the past. The principles of the respect of the authority and a hierarchical structure well defined are called into question. Today, the personnel estimates that the social qualification rests on other considerations that the functions economic.

The authority is not essential any more, but it is exerted by the presentation of tangible results, the participation of all in certain decision-makings and a more important collaboration between the members of the personnel. 
The manager of undertaking will have to hold account of the human purpose in his economic action, although this one remains dominating. If it were different, the survival even of the company would be put in danger.

The challenge of the communication - the company often made silence, maintaining this fact an absence of often alarming communication. However, which the company conceals, some is ready to reveal it, with the risk to deform it or invent it. In work of the Congress of Madrid of the International Chamber of Commerce, it with was stressed that the company should make accounts sincere to its public, in adapted languages.

Being one of the principal economic actors, the company is indebted information with regard to all those which are interested by its action or which are suitable for affected its existence or its development.

To this end, it is necessary to set up a policy of communication clear, sincere, adapted to the objectives to reach.

The utility of information, it is to inform, and not to allure. It is only by respecting this principle that one will manage to set up a system of effective diffusion of information.

The challenge of accountancy and financial information - the economic world and social A, for a long time, recognized the major role of accountancy as an essential tool of information to any person wishing to take responsibilities in management for a company, which is public or private. There are several factors which explain the importance taken by accountancy:

- the development and the reinforcement of the countable legislation generated new obligations as regards and presentation book-keeping of annual statements;

- legal recognition of the occupation of countable expert;

- the increase in the legal requirements as regards control of the accounts of the companies.

It is, so imperative to make sure that the countable situations presented by the companies are in conformity with the legal provisions, in particular as regards establishment of annual statements. Those include/understand the assessment, the income statement and the appendices, whose importance is not any more to underline, because they contain many information relating to the amounts appearing in the assessment and the income statement, but also in the rights of engagements which result from the existence of a contractual obligation. In addition, information economic and financial provided to the council of company is certified, which guarantees the reliability of the information relating to the company.

In a permanent preoccupation with a communication, the financial information intended for the thirds occupies an increasingly large place. The importance increased on the one hand by the legal requirements and on the other hand by the repeated requests for an increasingly large audience: financial analysts, economic journalists, shareholders, lenders of capital. It is necessary to place at the disposal of all documents of quality which it is important to include/understand, analyzing and interpreting.

\section{The increase in the requirements as regards financial information}

The future requirements with regard to the diffusion of the financial data will be with the image of the challenges described previously. It will be necessary, to answer it effectively, of the rigor, clearness and reliability. The credibility of the established information and official statements will be ensured by certification of professionals of control, independent and qualified. The requirements in this field can be gathered according to following categories':

a) needs for relevant, comprehensible and reliable information. The relevance increases quality by

it, comprehension facilitates the action to be undertaken and reliability allows their objective use;

b) the need for countable and national and international tax matter information;

c) the need for social information allowing to know for example, the cost of the personnel or welfare benefits granted or received at the time of investments human or materials; 
d) the need for dialogue with the countable expert in order to better determine the information useful for the decision-making, the manner of collecting them, of treating them and of presenting them;

e) the need for necessary countable knowledge to comply with the legal and professional regulations;

f) the need for analysis and interpretation of the countable and financial data established and diffused by the company.

The systematic study of the capitalization of a company constitutes a fundamental stage in the analysis of the annual statements. Indeed, they are only while being based on a balanced management of employment and resources that the leader will be able to lay down objectives in the short and medium term. Thanks to this approach, the observer is able to draw the first conclusions on the health of the company. The detailed examination of the liability of the assessment makes it possible to appreciate the choice of adopted financing: does there exists a relationship adequate between the own capital stocks and the debt? The answer to this first question will be related to several internal or external elements to the company (interest rate, conditions of operating, speed of circulation). In addition, which is the importance of the resources placed at the disposal of the company in a permanent way?

The opinion that one can emit on the financial policy will also depend on the way whose resources are used, i.e. structure of the credit. The decomposition of the uses in fixed assets and capital working will make it possible to judge the policy of investments (more intense in the industrial companies), or unlike a use of financial means to cover the cycle purchases sales (case of the trade undertakings). On this subject, the income statement and the appendices we will provide judicious indications. For example, the interpretation of the level of stocks and the commercial credits will be always established on the basis of calculation of the rotation of these two elements because an improvement of this one is likely to have a favorable influence on the financial standing.

The basic rule of financial balance supposes a null or positive cash flow statement. To this end, the existence of a working capital positive Net is of primary importance. This one makes it possible to check the financing of stable employment by the permanent resources and to release a safety margin intended to cover the inherent risks in certain stations of the working capital. In the event of imbalance, it is recommended to the managers to take measurement adequate to cure the situation: increase in the invested capital and/or reduction in the fixed assets.

That is to measure the financial incidence of a decision-making (analyzes intern) or to determine the health of a concurrent company (analyzes external), the annual statements and other book and financial regularly require a rigorous examination and an objective interpretation of the results obtained.

\section{BIBLIOGRAPHY:}

1. Călin O., Cărstea Gh., Contabilitatea de gestiune şi calculaţia costurilor, Ed. Genicod,Bucureşti, 2002

2. Căpuşneanu S., Contabilitatea de gestiune şi calculaţia costurilor, Ed. Economică, Bucureşti, 2003

3. Cote Y.A., La fonction comptable et le contrôle dans le mouvance de l'avenir, Montreal 2001

4. Cucui I., Horga V., Radu M., Contabilitate de gestiune, Ed. Niculescu, Bucureşti, 2003

5. Cucui I., Horga V., Radu M., Control de gestiune, Ed. Niculescu, Bucureşti, 2003

6. Diaconu P., Albu N., Mihai S., Albu, C., Guinea, F., Contabilitate managerială aprofundată, Ed. Economică, Bucureşti, 2003

7. Ebbeken K., Possler L., Ristea M., Calculaţia şi managementul costurilor, Ed. Teora, Bucureşti, 2000

8. Filip A. T., Ionaşcu I., Mihai S., Control de gestiune, Ed. ASE, Bucureşti, 2002 
9. Hirigoyen G, Boyer A., Thépont J., Turnois N., Védrine J.P., Les fondamentaux de l'entreprise, Ed. Organisation, Paris, 2004

10. Leclère D., Lesel Ph., Dubrulle L., Control de gestiune, traducere, colecția ROMEXCO, Ed.Economică, Bucureşti, 2000

11. Leclère D., L'essentiel de la comptabilité analitique, Ed. Organisation, Paris, 2004

12. Obert R., Pratique des normes IAS/IFRS, Ed. Dunod, Paris, 2003 